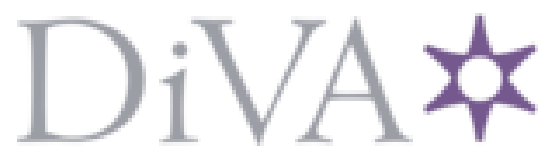

http://www.diva-portal.org

This is the published version of a paper published in FEBS Letters.

Citation for the original published paper (version of record):

Askerlund, P., Larsson, C., Widell, S. (1988)

Localization of donor and acceptor sites of NADH dehydrogenase activities using inside-out and right-side-out plasma membrane vesicles from plants.

FEBS Letters, 239(1): 23-28

http://dx.doi.org/10.1016/0014-5793(88)80538-6

Access to the published version may require subscription.

N.B. When citing this work, cite the original published paper.

Open Archive article

Permanent link to this version:

http://urn.kb.se/resolve?urn=urn:nbn:se:hj:diva-3869 


\title{
Localization of donor and acceptor sites of NADH dehydrogenase activities using inside-out and right-side-out plasma membrane vesicles from plants
}

\author{
Per Askerlund, Christer Larsson and Susanne Widell \\ Department of Plant Physiology, University of Lund, PO Box 7007, S-220 07 Lund, Sweden
}

Received 2 August 1988

\begin{abstract}
Inside-out and right-side-out plasma membrane vesicles from sugar beet (Beta vulgaris L.) leaves, prepared by aqueous two-phase partitioning, were used to localize donor and acceptor sites and to determine substrate affinities for plasma membrane-bound NADH dehydrogenase activities. NADH-ferricyanide and NADH-cytochrome $c$ reductase activities were approx. 30\% latent with inside-out vesicles and about $80 \%$ latent with right-side-out vesicles, indicating that both donor and acceptor sites for these activities are located on the cytoplasmic surface of the plasma membrane, and that a possible transplasma membrane electron transport would constitute only a minor proportion of the total activity.
\end{abstract}

Plasma membrane; Inside-out vesicle; Redox chain; Enzyme kinetics; NADH-ferricyanide reductase; NADH-cytochrome $c$ reductase

\section{INTRODUCTION}

The redox activities associated with plant plasma membranes (PMs) are currently attracting much interest. Such activities have been observed with intact plants, cell cultures and purified PM preparations [1-3]. These PM-associated activities have been suggested to participate in several physiological processes, such as ion transport and hormonal regulation of cell growth [2-5]. With intact plants, tissues and cells, the PM redox system can reduce exogenous electron acceptors such as ferricyanide $(\mathrm{FeCN})[3,6]$, which suggests the presence of a transplasma membrane electrontransport system. The natural electron acceptor is not known, however, in young roots of nongraminaceous plants for example, it may be $\mathrm{Fe}$ chelates since they possess an $\mathrm{Fe}^{3+}$-reduction

Correspondence address: P. Askerlund, Department of Plant Physiology, University of Lund, PO Box 7007, S-220 07 Lund, Sweden

Abbreviations: cyt., cytochrome(s); FeCN, ferricyanide; $\mathrm{PM}(\mathrm{s})$, plasma membrane(s); $\mathrm{PpBQ}$, phenyl-p-benzoquinone system which is induced by iron deficiency [7]. An auxin-stimulated NADH oxidase has been purified from soybean hypocotyl PMs [5], therefore $\mathrm{O}_{2}$ may be a natural electron acceptor in other tissues. The physiological reductant for the PM oxidoreductases appears to be cytoplasmic NADH or NADPH [1-3,7], but oxidation of exogenous NAD(P)H by cells and tissues has been reported in several cases $[6,8]$. Isolated PM preparations of high purity have been reported to reduce artificial electron acceptors $[9,10]$, ascorbate free radical [11] and to a lesser extent $\mathrm{O}_{2}[10,12,13]$ in the presence of NAD(P)H. NADH seems to be preferred to NADPH with PMs from some sources $[10,11]$, however with PMs from different origins the activities are similar [9]. An NADH-FeCN reductase has been partially purified from PMs of maize roots [11].

In PM preparations consisting mainly of rightside-out $\quad(70-90 \%$ apoplastic side-out) [14] vesicles, $\mathrm{NAD}(\mathrm{P}) \mathrm{H}$ dehydrogenase activities show high latencies (large increase in activity on addition of Triton X-100) with impermeable electron acceptors such as FeCN and cyt. $c$, as well as with duroquinone $[10,11,15]$. If it is assumed that the sole 
effect of the detergent is to allow the added substrates to gain access to their active sites on the membrane surface, the reasons for the latency could be either that $\mathrm{NAD}(\mathrm{P}) \mathrm{H}$ or the acceptor has its active site on the cytoplasmic surface of the PM, or that both have their active sites on the cytoplasmic surface of the PM. A transplasma membrane electron-transport chain which could reduce $\mathrm{Fe}^{3+}$ at the apoplastic surface should have the donor and acceptor site(s) on the cytoplasmic and apoplastic surfaces, respectively. To obtain positive evidence for the orientation of donor and acceptor sites, it is necessary to have vesicles of opposite orientation. Very recently, we succeeded in separating inside-out and right-side-out PM vesicles from leaves of sugar beet [16]. We have now used these PM vesicles to determine the orientation of the active sites for NADH and the electron acceptors FeCN and cyt. $c$ as well as the $K_{\mathrm{m}}$ values for these substrates.

\section{MATERIALS AND METHODS}

\subsection{Plant material}

Light-grown 4-8-week-old sugar beet plants (Beta vulgaris L.), kindly supplied by Hilleshög AB, Sweden, were used.

\subsection{Plasma membranes}

PMs of inside-out and right-side-out orientation were prepared from sugar beet leaves as described in [16], except that dithiothreitol was omitted from the medium used during the final centrifugation as well as from the resuspension medium to decrease NADH-independent reduction of electron acceptors in the assays. Based on the latency of the $\mathrm{K}^{+}$-stimulated, $\mathrm{Mg}^{2+}$-dependent ATPase, the inside-out fraction contained $\sim 90 \%$ sealed inside-out vesicles whereas the right-side-out fraction contained $\sim 90 \%$ sealed, right-side-out vesicles [16].

\subsection{Enzyme assays}

NADH-FeCN reductase activity was determined with an Aminco DW 2 spectrophotometer operated in the dual-beam mode by following the reduction of FeCN at 420 minus $500 \mathrm{~nm}$ at $25^{\circ} \mathrm{C}$. The standard reaction mixture contained $25 \mathrm{mM}$ Hepes- $\mathrm{KOH}$ (pH 7.3), or $50 \mathrm{mM}$ Tris-acetate $(\mathrm{pH} \mathrm{7.3),0.33} \mathrm{M}$ sucrose, $1 \mathrm{mM} \mathrm{K}_{3}\left[\mathrm{Fe}(\mathrm{CN})_{6}\right], 0.4 \mu \mathrm{M}$ antimycin $\mathrm{A}, 1 \mathrm{mM} \mathrm{KCN}$ and $20-50 \mu \mathrm{g}$ membrane protein in a volume of $1.0 \mathrm{ml}$. The reaction was initiated by the addition of $0.25 \mathrm{mM} \mathrm{NADH}$. Correction was always made for non-enzymatic reduction of $\mathrm{FeCN}$.

NADH-cyt. $c$ reductase activity was measured under the same conditions as for NADH-FeCN reductase except that $40 \mu \mathrm{M}$ cyt. $c$ (final concentration) was substituted for $\mathrm{K}_{3}\left[\mathrm{Fe}(\mathrm{CN})_{6}\right]$. The activity was recorded at 550 minus $600 \mathrm{~nm}$. When $K_{\mathrm{m}}$ values were determined the assay mixture also included $7.5 \mathrm{mM}$
$\mathrm{MgCl}_{2}$, and during measurement of $K_{\mathrm{m}}$ for $\mathrm{FeCN}$ the concentration of NADH in the assay was increased to $0.5 \mathrm{mM}$.

NADH-PpBQ reductase was determined by following the oxidation of NADH at $340 \mathrm{~nm}$. A correction (11\%) was made for the simultaneous decrease at $340 \mathrm{~nm}$ due to reduction of $\mathrm{PpBQ}$, assuming an NADH/PpBQ stoichiometry of 1 . The reaction mixture was the same as for NADH-FeCN reductase except that $0.2 \mathrm{mM}$ PpBQ (final concentration), added in a volume of $5 \mu \mathrm{l}$ dimethyl sulfoxide, was substituted for $\mathrm{K}_{3}\left[\mathrm{Fe}(\mathrm{CN})_{6}\right]$. The reaction was started by the addition of membranes to allow subtraction of non-enzymatic oxidation of NADH.

The values of the extinction coefficients used were 1, 19, 6.2 and $0.8 \mathrm{mM}^{-1} \cdot \mathrm{cm}^{-1}$ for $\mathrm{FeCN}$, cyt. $c$, NADH and PpBQ, respectively.

\subsection{Protein}

Protein was measured essentially as in [17], using bovine serum albumin as standard.

\section{RESULTS}

\subsection{Latencies of NADH dehydrogenase activities}

The capacity of PM vesicles with opposite orientation to oxidize NADH in the presence of different artificial electron acceptors was investigated. In the absence of Triton X-100 the activity was much higher with inside-out than rightside-out PM vesicles for all electron acceptors tested, whereas in the presence of Triton X-100 the activities were similar in both vesicle types (table 1). Thus, the latencies of NADH-dehydrogenase activities were low with inside-out vesicles and high with right-side-out vesicles. The considerable differences in latency between the two fractions were not due to different concentration optima for Triton X-100, since both showed maximal activity at the Triton concentrations used (fig.1). NADHFeCN reductase activity reached a plateau above $0.015 \%$ Triton $\mathrm{X}-100$, while that with cyt. $c$ decreased at concentrations above $\sim 0.015 \%$ (fig. 1), the exact optimum being dependent on the protein concentration (not shown). The Triton dependency with $\mathrm{PpBQ}$ was similar to that with FeCN (not shown). A greater latency was observed with PpBQ with inside-out PMs than with $\mathrm{FeCN}$ and cyt. $c$, however, with right-side-out PMs the latency was the same as with $\mathrm{FeCN}$ (table 1). No oxidation of NADH was observed in the absence of added electron acceptor, indicating that $\mathrm{O}_{2}$ could not serve as an acceptor with these preparations, at variance with previous reports for PM from other sources $[12,13]$. 
Table 1

NADH dehydrogenase activities of inside-out (IO) and rightside-out (RO) plasma membrane vesicles with different electron acceptors

\begin{tabular}{|c|c|c|c|}
\hline \multirow[t]{2}{*}{ Vesicle (unit) } & \multicolumn{3}{|c|}{$\begin{array}{l}\text { NADH-acceptor dehydrogenase } \\
\text { activity }\end{array}$} \\
\hline & $\mathrm{FeCN}$ & Cyt. $c$ & $\mathrm{PpBQ}$ \\
\hline IO (spec. act.) $)^{a}$ & $655 \pm 186$ & $200 \pm 58$ & $198 \pm 56$ \\
\hline IO + TX 100 (spec. act.) & $936 \pm 192$ & $263 \pm 53$ & $326 \pm 40$ \\
\hline Latency $(\%)$ & $30 \pm 13$ & $25 \pm 6$ & $40 \pm 14$ \\
\hline RO (spec. act.) & $177 \pm 47$ & $43 \pm 9$ & $40 \pm 22$ \\
\hline \multicolumn{4}{|l|}{$\mathrm{RO}+\mathrm{TX} 100$} \\
\hline (spec. act.) & $1090 \pm 224$ & $202 \pm 63$ & $270 \pm 30$ \\
\hline Latency $(\%)$ & $83 \pm 5$ & $75 \pm 4$ & $84 \pm 1$ \\
\hline
\end{tabular}

a nmol reduced acceptor $\cdot \min ^{-1} \cdot(\mathrm{mg} \text { protein })^{-1}( \pm \mathrm{SD})$ in the case of $\mathrm{FeCN}$ and cyt. $c$, and nmol oxidized $\mathrm{NADH} \cdot \min ^{-1} \cdot(\mathrm{mg} \text { protein })^{-1} \pm \mathrm{SD}$ for $\mathrm{PpBQ}$

Data represent means from measurements on the same 4 membrane preparations. Triton X-100 (TX 100) was used at $0.015 \%(\mathrm{w} / \mathrm{v})$ in the case of cyt. $c$ and at $0.025 \%(\mathrm{w} / \mathrm{v})$ for $\mathrm{FeCN}$ and $\mathrm{PpBQ}$. Latency is defined as:

(activity with TX 100) - (activity without TX 100)

(activity without TX 100)

\subsection{Kinetic characterization of NADH-FeCN and $N A D H$-cyt. c reductase activities with inside-out and right-side-out plasma membrane vesicles}

$K_{\mathrm{m}}$ values for NADH were determined with inside-out and right-side-out PMs in the presence of Triton X-100, as well as with inside-out PMs in the absence of this detergent (fig.2A,B; table 2). We also attempted to measure $K_{\mathrm{m}}(\mathrm{NADH})$ for FeCN reductase with right-side-out PMs in the absence of Triton X-100, however, the results were erratic due to the very low activities and are not presented here. No significant differences for $K_{\mathrm{m}}(\mathrm{NADH})$ were observed between the two vesicle fractions with either $\mathrm{FeCN}$, or cyt. $c$ (table 2), nor was any evidence found in support of the existence of more than one component, i.e. straight lines were obtained with high regression coefficients (fig.1A,B). In contrast, there was a significant difference in $K_{\mathrm{m}}(\mathrm{NADH})$ values between NADH$\mathrm{FeCN}$ and NADH-cyt. $c$ reductase activities, the affinity for NADH of the latter activity being 4-times higher (table 2).

The $K_{\mathrm{m}}$ values for $\mathrm{FeCN}$ and cyt. $c$ with insideout vesicles could only be determined accurately in

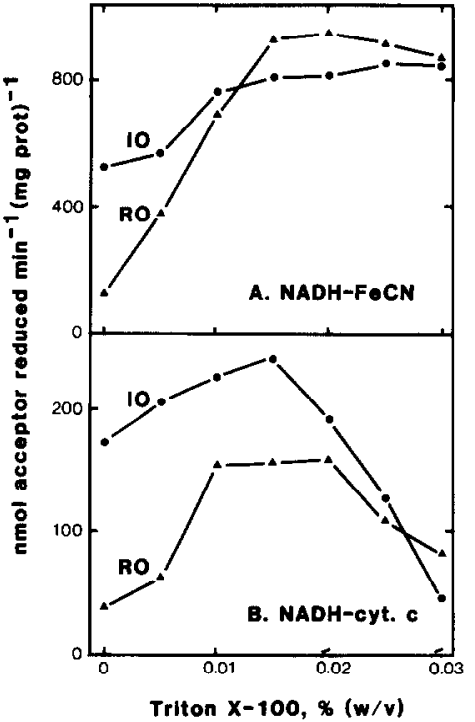

Fig.1. Effect of Triton X-100 on NADH-FeCN (A) and NADHcyt. $c(B)$ reductase activities of inside-out $(\bullet)$ and right-sideout (A) plasma membrane vesicles. Protein concentration, $50 \mu \mathrm{g} \cdot \mathrm{ml}^{1}$.
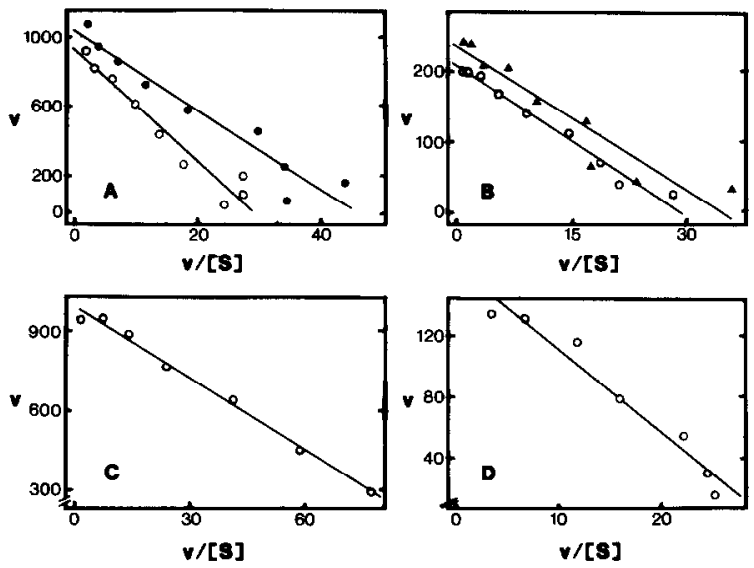

Fig.2. Eadie-Hofstee plots for determination of $K_{\mathrm{m}}$ values. (A) $K_{\mathrm{m}}(\mathrm{NADH})$ for NADH-FeCN reductase of inside-out PM vesicles in the absence $\left(O, K_{\mathrm{m}}=22 \mu \mathrm{M}, R=0.96\right)$ and presence $\left(\bullet, K_{\mathrm{m}}=32 \mu \mathrm{M}, R=0.97\right)$ of $0.025 \%$ (w/v) Triton $\mathrm{X}-100$. (B) $K_{\mathrm{m}}(\mathrm{NADH})$ for NADH-cyt. $c$ reductase of insideout PM vesicles in the absence of Triton X-100 $\left(0, K_{\mathrm{m}}=\right.$ $7.1 \mu \mathrm{M}, R=0.99$ ), and of right-side-out $\mathrm{PM}$ vesicles in the presence $\left(\Delta, K_{\mathrm{m}}=6.8 \mu \mathrm{M}, R=0.94\right)$ of $0.015 \%$ Triton X-100. (C) $K_{\mathrm{m}}(\mathrm{FeCN})$ for NADH-FeCN reductase of inside-out PM vesicles in the absence of Triton X-100 $\left(K_{\mathrm{m}}=9.0 \mu \mathrm{M}, R=1.0\right)$. (D) $K_{\mathrm{m}}$ (cyt. c) for NADH-cyt. $c$ reductase of inside-out PM vesicles in the absence of Triton X-100 $\left(K_{\mathrm{m}}=5.4 \mu \mathrm{M}, R=\right.$ $0.98) . v=\mathrm{nmol}$ acceptor reduced $\cdot \min ^{-1} \cdot(\mathrm{mg} \text { protein })^{-1} . S$, substrate concentration $(\mu \mathrm{M}) . R$, regression coefficient obtained after linear regression analysis. $9(\mathrm{~A}, \mathrm{~B})$ or $7(\mathrm{C}, \mathrm{D})$ concentrations were used for each plot. 
Table 2

$K_{\mathrm{m}}$ values for NADH, FeCN and cyt. $c$ obtained with inside-out (IO) and right-side-out (RO) plasma membrane vesicles

\begin{tabular}{|c|c|c|c|c|}
\hline \multirow[t]{3}{*}{ Vesicles } & \multicolumn{4}{|c|}{$K_{\mathrm{m}}(\mu \mathrm{M})$} \\
\hline & \multicolumn{2}{|c|}{$\begin{array}{l}\text { NADH-FeCN } \\
\text { reductase }\end{array}$} & \multicolumn{2}{|c|}{$\begin{array}{l}\text { NADH-cyt. } c \\
\text { reductase }\end{array}$} \\
\hline & NADH & $\mathrm{FeCN}$ & NADH & Cyt. $c$ \\
\hline IO & $\begin{array}{l}30 \pm 8 \\
(n=3)\end{array}$ & $\begin{array}{c}8.0 \pm 1.4 \\
(n=2)\end{array}$ & $\begin{array}{c}7.6 \pm 0.7 \\
(n=2)\end{array}$ & $\begin{array}{c}4.1 \pm 1.3 \\
(n=2)\end{array}$ \\
\hline $10+\operatorname{TX} 100$ & $\begin{array}{l}25 \pm 3 \\
(n=4)\end{array}$ & NT & $\begin{array}{c}6.6 \pm 0.3 \\
(n=2)\end{array}$ & NT \\
\hline $\mathrm{RO}+\mathrm{TX} 100$ & $\begin{array}{l}33 \pm 7 \\
(n=3)\end{array}$ & NT & $\begin{array}{c}8.0 \pm 1.4 \\
(n=2)\end{array}$ & NT \\
\hline
\end{tabular}

Concentrations of Triton X-100 (TX 100) as in table 1. NT, not tried. $n$, number of membrane preparations tested

the absence of detergent (table 2), since Triton $\mathrm{X}-100$ released reducing compounds from the vesicles (originating from the homogenization medium) which interfered with measurements at very low concentrations of acceptor. No evidence for more than one component was obtained in determinations of $K_{\mathrm{m}}$ values for $\mathrm{FeCN}$ and cyt. $c$ (fig.2C,D). With right-side-out vesicles in the absence of Triton, activities were too low for the determination of $K_{\mathrm{m}}$ values for either electron acceptor.

During determination of $K_{\mathrm{m}}$ values for NADH and $\mathrm{FeCN}$ it was noted that $7.5 \mathrm{mM} \mathrm{Mg}^{2+}$ increased the activities approx. 2-fold at low concentrations of NADH and ferricyanide, respectively. This was probably due to screening of the net negative charge on the PM [18] by the cation, as has been reported for mitochondrial inner membrancs [19]. The effect of $\mathrm{Mg}^{2+}$ was not further investigated, but $7.5 \mathrm{mM} \mathrm{MgCl}$ was always present in the assay medium during all measurements on the kinetics in order to maintain the surface potential at a low value. This ensures that the $K_{\mathrm{m}}$ values obtained are close to the 'true' values.

\section{DISCUSSION}

The membrane-impermeable electron donor $\mathrm{NADH}$, and the impermeable electron acceptors $\mathrm{FeCN}$ and cyt. $c$, as well as the membranepermeable acceptor PpBQ [20] were used to localize donor and acceptor sites of PM NADH dehydrogenases using inside-out and right-side-out $P M$ vesicles. The rationale was that impermeable substrates would only indicate the activities when both donor and acceptor sites are located on the same side of the membrane, whereas a permeable acceptor would also record transmembrane electron transport provided that the donor site is on the exposed surface of the membrane vesicle. Addition of detergent will rupture the vesicles, expose all sites and give $100 \%$ activity.

The latencies obtained with $\mathrm{FeCN}$ and cyt. $c$ as acceptors clearly indicate that both the active sites for NADH-FeCN and NADH-cyt. $c$ reductase are located on the cytoplasmic surface of the PM. Trans-membrane electron transport from NADH to these acceptors could at most constitute approx. $30 \%$ of the total activities, since the latencies with inside-out vesicles were only about $30 \%$ (table 1 ). However, this $30 \%$ increase in activity could also be due to contamination of inside-out vesicles by $30 \%$ right-side-out vesicles, although the latency of the $\mathrm{K}^{+}$-stimulated, $\mathrm{Mg}^{2+}$-dependent ATPase indicated only $10 \%$ contamination [16]. The hydrophobic acceptor PpBQ should be able to accept electrons on both sides of the PM and NADHPpBQ reductase should therefore only show NADH latency. The latency of this activity should thus provide a better measure of the degree of contamination by right-side-out vesicles. Surprisingly, PpBQ exhibited greatest latency $(40 \%$, table 1$)$ with inside-out vesicles, which appears to exclude the possibility of transplasma membrane electron transport. However, an increase in activity on addition of detergent may not only be due to rupturing of vesicles with concomitant exposure of hidden sites, but may also be the result of stimulation of the activity by some other mechanism. This second possibility may explain the relatively high latency obtained with $\mathrm{PpBQ}$ and inside-out vesicles. Therefore, the possibility that transmembrane electron transport makes a minor contribution to the total activity cannot be excluded. In agreement with our results, Morré et al. [21] have observed reduction of FeCN by NADH only at the cytoplasmic surface in PM vesicles from soybean hypocotyls using a cytochemical method. Furthermore, Giannini and Briskin [22], working with a crude PM fraction from red beet storage tissue, obtained no evidence of transmembrane electron transport from NADH to FeCN. 
However, results obtained with intact plant tissues and cells $[2,3,5,6]$, as well as with animal material $[1,2]$ strongly suggest that transplasma membrane electron transport from $\mathrm{NAD}(\mathrm{P}) \mathrm{H}$ to $\mathrm{FeCN}$ does occur. Indeed, data obtained using animal material show that even if only $10 \%$ of the NADH-FeCN reductase activity measured with isolated PMs were transplasma membranous, it could still account for the rates determined for intact cells [1].

The presence of one major NADH-FeCN reductase with both donor and acceptor sites on the cytoplasmic surface of the PM was further supported by the $K_{\mathrm{m}}$ measurements (table 2, fig. $2 \mathrm{~A}, \mathrm{C}$ ). Eadie-Hof stee plots for determination of the $K_{\mathrm{m}}$ values for $\mathrm{NADH}$ and $\mathrm{FeCN}$ demonstrated only one component, and the $K_{\mathrm{m}}$ values for $\mathrm{NADH}$ were very similar irrespective of the vesicle fraction used and of the presence or absence of Triton X-100. Similarly, measurements of $K_{\mathrm{m}}(\mathrm{NADH})$ and $K_{\mathrm{m}}$ (cyt. c) for NADH-cyt. $c$ reductase also indicated one major activity with donor and acceptor sites on the cytoplasmic surface of the PM. However, $K_{\mathrm{m}}$ measurements yielded no information on the possible acceptor sites for $\mathrm{FeCN}$ and cyt. $c$ on the apoplastic side of the $\mathrm{PM}$, since it was not possible to measure the parameters for these acceptors in the presence of Triton (see section 3.2). The $K_{\mathrm{m}}$ values for NADH of the $\mathrm{FeCN}$ and cyt. $c$ reductases differed by a factor of 4, suggesting that the activities stem from different enzymes. Alternatively, $K_{\mathrm{m}}(\mathrm{NADH})$ may be influenced by the redox state of the different electron carriers in a presumptive common chain from NADH to cyt. $c$ via an acceptor site for $\mathrm{FeCN}[1,2]$.

It is possible that the NADH-FeCN and NADHcyt. $c$ reductase (and NADH-PpBQ reductase) activities of the PM may all be due to NADH-cyt. $b_{5}$ reductase. Thus, the reduction of $\mathrm{FeCN}$ (and cyt. c) by this enzyme is not a transmembrane process. The presence of cyt. $b_{5}$ in PMs from sugar beet leaves is indicated by low-temperature spectra (Askerlund, P. et al., unpublished). Assayed as antimycin A-insensitive NADH-cyt. $c$ reductase activity, the NADH-cyt. $b_{5}$ reductase is widely used as a marker for the endoplasmic reticulum, however, in animal cells the activity is present in all endomembranes [1] and in plants it has been reported in glyoxysomes [23,24] and tonoplast [9]. In addition, both animal and plant PMs also possess this activity $[1,3,10,11]$ (table 1), possibly because endomembranes undergo active exchange with the PM ([1] and references cited therein). Cyt. $b_{5}$ is required for reduction of cyt. $c$ by NADH-cyt. $b_{5}$ reductase, but not in the case of $\mathrm{FeCN}$ which is reduced directly at the dehydrogenase $[1,25]$. Triton X-100 was inhibitory at levels above approx. $0.015 \%(\mathrm{w} / \mathrm{v})$ with cyt. $c$ but not with $\mathrm{FeCN}$ (fig.1), which may suggest that this detergent disrupts the connection between the dehydrogenase and cyt. $b_{5}$ in the PM.

In conclusion, our data show that donor and acceptor sites for both NADH-FeCN and NADHcyt. $c$ reductase are located on the cytoplasmic surface of the PM whereas no evidence supportive of the donor or acceptor sites residing on the apoplastic surface was found. If a transplasma membrane redox chain does exist, it only constitutes a small proportion of total PM redox activity.

Acknowledgements: We wish to thank Mrs Adine Karlsson for skilful technical assistance. We are grateful to Dr Ian M. Moller for valuable discussions. This work was supported by grants from the Swedish Natural Science Research Council (NFR) and the Carl Tesdorpf foundation.

\section{REFERENCES}

[1] Crane, F.L., Löw, H. and Clark, M.G. (1985) in: The Enzymes of Biological Membranes (Martonosi, A.N. ed.) vol.4, pp.465-510, Plenum, New York.

[2] Crane, F.L., Sun, I.L., Clark, M.G., Grebing, C. and Löw, H. (1985) Biochim. Biophys. Acta 811, 233-264.

[3] Møller, I.M. and Lin, W. (1986) Annu. Rev. Plant Physiol. 37, 309-334.

[4] Lüttge, U. and Clarkson, D.T. (1985) Prog. Bot. 47, 7386.

[5] Brightman, A.O., Barr, R., Crane, F.L. and Morré, D.J. (1988) Plant Physiol. 86, 1264-1269.

[6] Rubinstein, B., Stern, A.I. and Stout, R.G. (1984) Plant Physiol. 76, 386-391.

[7] Bienfait, H.F. (1985) J. Bioenerg. Biomembranes 17, 73-83.

[8] Lin, W. (1982) Proc. Natl. Acad. Sci. USA 79, $3773-3776$.

[9] Barr, R., Sandelius, A.S., Crane, F.L. and Morré, D.J. (1986) Biochim. Biophys. Acta 852, 254-261.

[10] Buckhout, T.J. and Hrubec, T.C. (1986) Protoplasma $135,144-154$.

[11] Luster, D.G. and Buckhout, T.J. (1988) Physiol. Plant. 73, 339-347.

[12] Barr, R., Sandelius, A.S., Crane, F.L. and Morré, D.J. (1985) Biochem. Biophys. Res. Commun. 131, 943-948. 
[13] Maller, I.M. and Bérczi, A. (1985) FEBS Lett. 193, 180-184.

[14] Larsson, C., Kjellbom, P., Widell, S. and Lundborg, T. (1984) FEBS Lett. 171, 271-276.

[15] Bérczi, A., Larsson, C., Widell, S. and Møller, I.M. (1988) Plant Soil, in press.

[16] Larsson, C., Widell, S. and Sommarin, M. (1988) FEBS Lett. 229, 289-292.

[17] Bearden, J.C., jr (1978) Biochim. Biophys. Acta 533, 525-529.

[18] Møller, I.M., Lundborg, T. and Bérczi, A. (1984) FEBS Lett. 167, 181-185.

[19] Edman, K., Ericson, I. and Møller, I.M. (1985) Biochem. J. 232, 471-477.
[20] Andersson, B. and Ảkerlund, H.-E. (1978) Biochim. Biophys. Acta 503, 462-472.

[21] Morré, D.J., Auderset, G., Penel, C. and Canut, H. (1987) Protoplasma 140, 133-140.

[22] Giannini, J.L. and Briskin, D.P. (1988) Arch. Biochem. Biophys. 260, 653-660.

[23] Hicks, D.B. and Donaldson, R.P. (1982) Arch. Biochem. Biophys. 215, 280-288.

[24] Luster, D.G. and Donaldson, R.P. (1987) Plant Physiol. $85,796-800$.

[25] Jollie, D.R., Sligar, S.G. and Schuler, M. (1987) Plant Physiol. 85, 457-462. 